\title{
EVALUATION OF FORAMEN MAGNUM IN DRY HUMAN SKULLS OF DAKSHINA KANNADA DISTRICT
}

\section{Remya K ${ }^{1}$, Pretty Rathnakar *2, Swathi ${ }^{3}$.}

${ }^{1}$ Lecturer, Department of Anatomy, K.S. Hegde Medical Academy, Deralakatte, Mangalore, Karnataka, India.

${ }^{* 2}$ Associate Professor, Department of Anatomy, K.S. Hegde Medical Academy, Deralakatte, M angalore, Karnataka, India.

${ }^{3}$ Associate Professor, Department of Anatomy, K.S. Hegde Medical Academy, Deralakatte, M angalore, Karnataka, India.

\section{ABSTRACT}

Background: Foramen magnum is situated in the posterior cranial fossa in anteromedian position. It is of great importance in anthropology, forensic medicine and skull base surgeries.

Objective: Calculate anteroposterior (AP), transverse diameter(TD), area of foramen magnum and to observe its various shapes.

Materials and Methods: 50 dry human skull bones of unknown sex was obtained from anatomy department. M easurements were taken by vernier calipers .SPSS 16 was used to calculate mean and standard deviation.

Results: M ean AP diameter was found to be $33.64 \pm 0.228 \mathrm{~mm}$, mean TD was $27.040 \pm 0.214 \mathrm{~mm}$ and M ean area was $714.99 \pm 0.844 \mathrm{~mm}^{2}$. Oval shaped foramen magnum was the most common variety (46\%). $20 \%$ was tetrahedral,16\% round ,14\% egg shaped $2 \%$ hexagonal and $2 \%$ irregular .

Conclusion: Present study focuses on morphometric and morphological variation in foramen magnum. This will be useful for anatomists, forensic experts, radiologists and neurosurgeons .

KEY WORDS: Foramen magnum, Anteroposterior, Transverse, Diameter, Area.

Address for Correspondence: Dr Pretty Rathnakar, Associate Professor, Department of Anatomy, K.S. Hegde M edical Academy, Deralakatte, M angalore, Karnataka, India.

E-Mail: prettyshrinath@gmail.com

\begin{tabular}{|l|l|}
\hline \multicolumn{3}{|c|}{ Access this Article online } \\
\hline Quick Response code & Web site: International Journal of Anatomy and Research \\
ISSN 2321-4287 \\
www.ijmhr.org/ijar.htm \\
\cline { 2 - 3 }
\end{tabular}

\section{INTRODUCTION}

Foramen magnum is situated in the posterior cranial fossa in anteromedian position .It is oval, being wider behind having anteroposterior diameter as its greatest [1]. It is encroached anterolaterally by occipital condyles and its posterior part is thin and semicircular [2].

It contains the lower end of medulla oblongata, meninges, vertebral arteries, spinal accessory nerves, membrana tectoria and apical ligament of dens [1]. Foramen magnum in latin means large aperture in skull . It is of great importance in anthropology, forensic medicine and skull base surgeries [3].

Transcondylar approach is being used frequently to access lesions of cervicomedullary junction and those ventral to brainstem [4]. Vital structures that pass through foramen magnum can 
undergo compression such as in cases of achondroplasia [5] and brain herniation [6]. Thus variations in dimensions and shape of foramen magnum is of great clinical significance.

\section{MATERIALS AND METHODS}

The study was conducted on 50 dry skulls of unknown sex and age obtained from department of anatomy and students studying in K.S Hedge M edical Academy, M angalore, Karnataka, India.

Fig. 1: M easurement of AP and TD of foramen magnum.
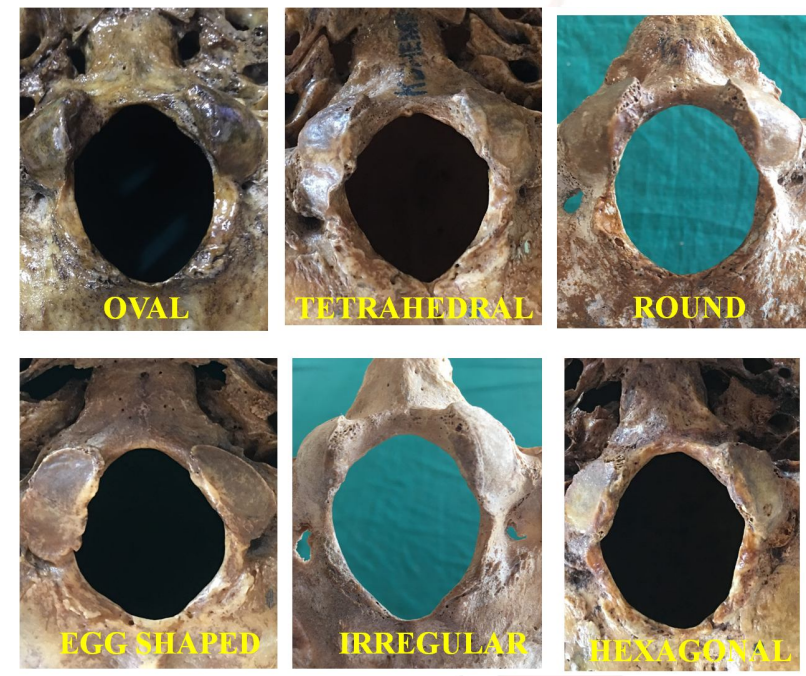

Fig. 2: Various shapes of foramen magnum in present study.

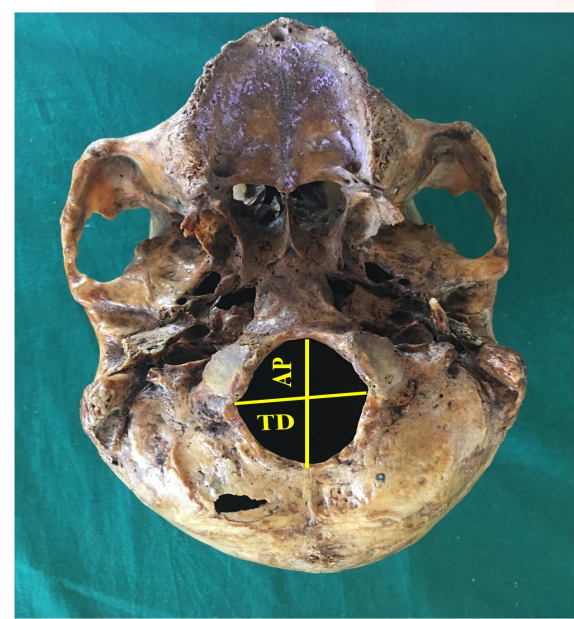

The parameters measured included:

Anteroposterior(AP) diameter of Foramen magnum: Distance between basion and opisthion.

Transverse diameter (TD) of foramen magnum: $M$ aximum diameter at the lateral margins.

All measurements were recorded using vernier callipers to an accuracy of $0.1 \mathrm{~mm}$. Two measurements were taken and average of two values were considered as final .
Area of foramen magnum was calculated by the formula [7].

$\operatorname{Area}(A)=1 / 4 \times 3.14 \times A P \times T D$

$M$ ean AP ,TD , area was calculated.

Mean and standard deviation were calculated using SPSS 16.

The various shapes of foramen magnum was observed by naked eye and were classified as oval ,round tetrahedral, egg shaped.

\section{RESULTS}

Dimensions of foramen magnum in the present study is mentioned in Table 1. In the present study we found oval shaped foramen magnum to be the most common variety (46\%). $20 \%$ was tetrahedral ,16\% round , $14 \%$ egg shaped $2 \%$ hexagonal and $2 \%$ irregular.

Table 1: Dimensions of foramen magnum.

\begin{tabular}{|c|c|c|c|}
\hline $\mathrm{N}=\mathbf{5 0}$ & Minimum & Maximum & Mean \pm SD \\
\hline $\mathrm{AP}(\mathrm{mm})$ & 30 & 37 & $33.64 \pm 0.228$ \\
\hline $\mathrm{TD}(\mathrm{mm})$ & 22 & 32 & $27.040 \pm 0.214$ \\
\hline $\mathrm{A}\left(\mathrm{mm}^{2}\right)$ & 588.7 & 904.3 & $714.99 \pm 0.844$ \\
\hline
\end{tabular}

Table 2: Comparison between present study and other studies regarding commonest variety of shape of foramen magnum.

\begin{tabular}{|c|c|c|}
\hline Study & $\begin{array}{c}\text { Shape of foramen } \\
\text { magnum }\end{array}$ & Percentage \\
\hline Aragao et al [20] & Pear shaped & $37.30 \%$ \\
\hline Radhika PM [21] & Oval & $40 \%$ \\
\hline Chetan et al [22] & Round & $22.60 \%$ \\
\hline Espinoza et al [23] & oval & $58 \%$ \\
\hline Present study & oval & $46 \%$ \\
\hline
\end{tabular}

DISCUSSION

Due to protected position of foramen magnum and relative more thickness of base of skull it is well preserved in most specimen [8]. Also it is least likely to undergo morphological changes Hence it is used frequently in anthropometry.

In the present study mean AP diameter was found to be $33.64 \pm 0.228 \mathrm{~mm}$ which is similar to study done by M uralidhar in 2014 (33.4mm) [9], Ganapathy in 2014(33.9mm)[10] and Patel and M ehta in 2014 (33.7mm) [11].

The mean AP diameter in the present study was found to be less than that by Anil Kumar in 2015(36.78mm)[12] Jain D in 2014 (36.2mm) [13] and Burdan in 2012 (37.06mm)[14]. 
In the present study mean TD was $27.040 \pm 0.214$ $\mathrm{mm}$ which is similar to study conducted by Singh and Talwar in 2013 (27.77mm)[15], Kanchan in $2013(27.36 \mathrm{~mm})$ [16] and Mahajhan D et al in $2013(27.47 \mathrm{~mm})$ [17].

TD in present study was less than that of study by Radhika P.M (29.4mm)[21] and by Ganapathy $(28.7 \mathrm{~mm})$ [10].

Mean area in our study was found to be $714.99 \pm 0.844 \mathrm{~mm}^{2}$ which is closer to study done by Singh and Talwar in $2013\left(733 \mathrm{~mm}^{2}\right)[15]$ ,M uralidhar in 2014( $\left.748.6 \mathrm{~mm}^{2}\right)$ [9] and Patel and Mehta in $2014\left(755.37 \mathrm{~mm}^{2}\right)$ [11] Studies which recorded more area than ours were Sampada PK $803.8 \mathrm{~mm}^{2}$ [18] and Anil kumar 876 $\mathrm{mm}^{2}$ [12].

Foramen magnum presents many important structures passing through it. Variations in shape and size of foramen magnum is thus important for surgeons incase they have to approach this region. Also foramen magnum compressions are noted in conditions such as achondroplasia and cerebral herniation [19].

Various types of shape of foramen magnum is quoted in literature .Various studies show disparity in the frequency of occurrence of different types of shape of foramen magnum. The various shapes described are oval, round, tetragonal, pentagonal, biconvex, hexagonal. Irregular etc. [20].

In the present study we found oval shape of foramen magnum to be the most commonest variety $(46 \%)$. $20 \%$ was tetrahedral , $16 \%$ round, $14 \%$ egg shaped $2 \%$ hexagonal and $2 \%$ irregular. We did not come across pentagonal and biconvex varieties. Comparison between present study and other studies regarding commonest variety of shape of foramen magnum is shown in Table 2.

\section{CONCLUSION}

Present study focuses on morphometric and morphological variation in foramen magnum. This will be useful for anatomists, forensic experts, radiologists and neurosurgeons. Further studies on the same can be done using $\mathrm{CT}$ scan and $M$ agnetic resonance imaging technique using more samples.

\section{Conflicts of Interests: None}

\section{ABBREVIATIONS}

AP - Anteroposterior

TD - Transverse diameter

A - Area

Mm - M illimetre

\section{REFERENCES}

[1]. Standring S. Gray's anatomy :the anatomical basis of clinical practice. $40^{\text {th }} \mathrm{Ed}$. Edinburgh: Elsevier Churchill Livingston 2008;414-15.

[2]. Romanes GJ. Cunningham's text book of anatomy. 12th Ed. Oxford : Oxford University Press; 1981.p.114.

[3]. Ferreira ,F. V, Rosenberg B, daLuz H.P. The Foramen magnum index in Brazilians. Rev .Fac.Odontol.Sao Paulo967;5(4):297-302.

[4]. Muthukumar N. Swaminathan R, Venkatesh G , Banumathy S.P. A morphometric analysis of the foramen magnum region as it relates to the transcon dylar approach . Acta Neurochirurgica 2005; 147(8):889-895.

[5]. Hecht TJ, Horton WA, Reid CS, et al. Growth of the foramen magnum in achondroplasia. American Journal of Medical Genetics 1989;32:528-35.

[6]. Reich JB, Sierra J, Camp W, et al. M agnetic resonance imaging measurements and clinical changes accompanying transtentorial and foramen magnum brain herniation. Annals of Neurology 1993;33:159-70.

[7]. Radinsky I.Relative brain size :a new measure .Science 1967;155:836-38.

[8]. Graw M. Morphometriche and morphognostiche .Geschlecths diagnostik an dermenschlichen Schadelbasis .In : Oehmicen M, Geserick(eds) Osteologiche identifikation and Altersschatzung Schmidt-Romhild, Lubeck 2001;103-121.

[9]. Muralidhar P. Shepur, Magi M , Nanjundappa B ,Pavan P Havaldar , Premlatha G, Shaik H .S. Morphometric analysis of foramen magnum . Int J Anat Res 2014;2(1):249-55.

[10]. Ganapathy A, Sadeesh T, Rao S. M orphometric Analysis of foramen magnum in adult human skulls and CT images .Int J Cur Res Rev 2014;6(20):11-15.

[11]. Patel R, CD M ehta. M orphometric study of foramen magnum at the base of human skull in South Gujarat.Journal of Dental and Medical Sciences 2014;13(6):23-25.

[12]. Kumar A, Dave M ,Sanam A. M orphometric evaluation of foramen magnum in dry human skulls. Int J Anat Res 2015;3(2):1015-23

[13]. Jain D, Jasuja OP, Nath $S$. Evaluation of foramen magnum in sex determination from human crania by using discriminant function analysis. E1 mednifco journal 2014;2(2):89-92.

[14]. Burdan Fet al . M orphology of the foramen magnum in young eastern Europian adults . Folia Morphol 2012;71(4):205-16.

[15]. Singh and Talwar. Morphometric analysis of foramen magnum in human skull for sex determination.Human Biology Review. 2013;2(1):29-41. 
[16]. Kanchan T, Gupta A, Krishan K. Craniometric analysis of foramen magnum for estimation of sex. International journal of medical, Health, biomedical and pharmaceutical engineering. 2013;7(7):111-113.

[17]. Mahajan D, Agnihotri G Sheth A, Brar R. An anatomical perspective of human occipital condyles and foramen magnum with neurosurgical correlates. International journal of clinical and experimental anatomy. 2013;6(7):29-33.

[18]. Sampada PK, Poornima B M allikarjun M, Santhosh B S. M orphometric and morphological study of foramen magnum in dried human skull bones. Int J Anat Res .2017;5(2.1):3682-86

[19]. Ropper A.H .M agnetic resonance imaging measurements and clinical changes accompanying transtentorial and foramen magnum brain herniation . Ann neurol1993;34(5):748-9.

[20]. Aragao J.A. ,Pereira R .D.O, M oraes R.Z.D.C.D, Reis F.P. M orphological types of foramen magnum. Annual research and review in biology2014;4(9):13721378
[21].Radhika.P.M , Shailaja Shetty ,Prathap K.J, C.Sheshgiri, Jyothi K.C. M orphometric study of the foramen magnum in adult human skulls in Indian population. Asian J M ed Clin Sci., 2014;3(2):68-72.

[22].P. Chethan, K.G. Prakash, B.V. Murlýmanju, K.U. Prashanth, Latha V. Prabhu, Vasudha V. Saralaya, Ashwin Krýshnamurthy, M.S. Somesh, C. Ganesh Kumar. Morphological analysis and morphometry of the foramen magnum: an anatomical investigation. Turkish Neurosurgery. 2012;22(4):416-419.

[23]. Espinoza E,Ayala C, Ortega L,collipal E. Silva $H$. Morfometria tomographica delforamen magno y surelacionconel sexo y la etnia mapuche. Rev. ANACEM (impresa)2011;5(1):28-31.

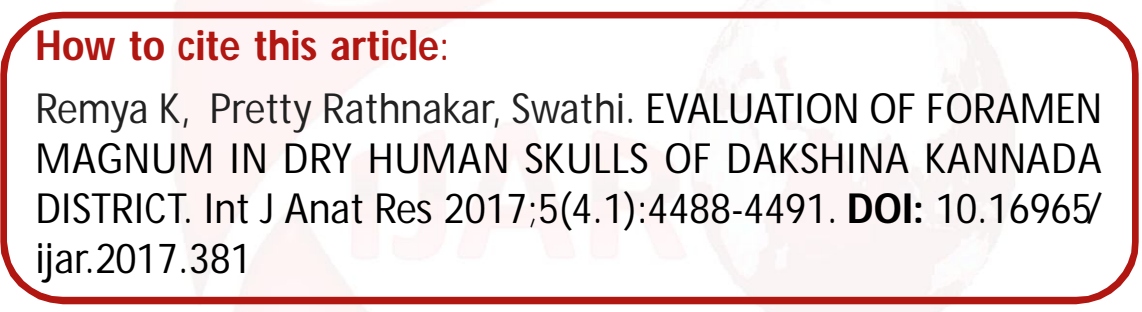

